Research Paper

\title{
Established Population of Blacklegged Ticks with High Infection Prevalence for the Lyme Disease Bacterium, Borrelia burgdorferi Sensu Lato, on Corkscrew Island, Kenora District, Ontario
}

\author{
John D. Scott ${ }^{1}$, Janet E. Foley², Kerry L. Clark³, John F. Anderson4, Lance A. Durden5, Jodi M. Manord³, \\ Morgan L. Smith ${ }^{3}$ \\ 1. Lyme Ontario, Research Division, 365 St. David St. South, Fergus, Ontario, Canada N1M 2L7; \\ 2. Department of Medicine and Epidemiology, School of Veterinary Medicine, University of California, Davis, California 95616, United States of America; \\ 3. Epidemiology \& Environmental Health, Department of Public Health, University of North Florida, 1 UNF Drive, Jacksonville, Florida 32224, United States \\ of America; \\ 4. Department of Entomology and Center for Vector Ecology and Zoonotic Diseases. The Connecticut Agricultural Experiment Station, P.O. Box 1106, New \\ Haven, Connecticut 06504-1106, United States of America; \\ 5. Department of Biology, Georgia Southern University, 4324 Old Register Road, Statesboro, Georgia 30458, United States of America. \\ $\bowtie$ Corresponding author: 365 St. David Street South, Ontario, Canada N1M 2L7. Telephone: 519-843-3646; Fax: 519-843-6550; e-mail: jkscott@bserv.com
}

( ) Ivyspring International Publisher. Reproduction is permitted for personal, noncommercial use, provided that the article is in whole, unmodified, and properly cited. See http://ivyspring.com/terms for terms and conditions.

Received: 2016.07.21; Accepted: 2016.09.26; Published: 2016.10.27

\begin{abstract}
We document an established population of blacklegged ticks, Ixodes scapularis, on Corkscrew Island, Kenora District, Ontario, Canada. Primers of the outer surface protein A (OspA) gene, the flagellin (fla) gene, and the flagellin $B(f l a B)$ gene were used in the PCR assays to detect Borrelia burgdorferi sensu lato (s.l.), the Lyme disease bacterium. In all, 60 (73\%) of 82 adult I. scapularis, were infected with $B$. burgdorferi s.l. As well, 6 (43\%) of 14 unfed I. scapularis nymphs were positive for B. burgdorferi s.l. An $I$. scapularis larva was also collected from a deer mouse, and several unfed larvae were gathered by flagging leaf litter. Based on DNA sequencing of randomly selected Borrelia amplicons from six nymphal and adult $I$. scapularis ticks, primers for the flagellin (fla) and flagellin B (flaB) genes reveal the presence of $B$. burgdorferi sensu stricto (s.s.), a genospecies pathogenic to humans and certain domestic animals. We collected all 3 host-feeding life stages of $I$. scapularis in a single year, and report the northernmost established population of $I$. scapularis in Ontario. Corkscrew Island is hyperendemic for Lyme disease and has the highest prevalence of B. burgdorferi s.l. for any established population in Canada. Because of this very high infection prevalence, this population of $I$. scapularis has likely been established for decades. Of epidemiological significance, cottage owners, island visitors, outdoors enthusiasts, and medical professionals must be vigilant that B. burgdorferi s.l.-infected $I$. scapularis on Corkscrew Island pose a serious public health risk.
\end{abstract}

Key words: blacklegged tick, Ixodes scapularis, Lyme disease, Borrelia burgdorferi, infection prevalence, Kenora District, Ontario

\section{Introduction}

The blacklegged tick, Ixodes scapularis (northern populations previously treated as I. dammini) (Acari: Ixodidae), is the principal North American vector of the Lyme disease bacterium, Borrelia burgdorferi sensu lato (s.l.) east of the Rocky Mountains [1]. In northern latitudes, I. scapularis typically has a 2-yr life cycle that consists of egg, larva, nymph, and adult (male, female), and has a diapause in the winter months throughout northwestern Ontario. Worldwide, the $B$. burgdorferi s.l. complex comprises of at least 23 genospecies or genomospecies. In North America, at least 10 B. burgdorferi s.l. genospecies/genomospecies are present, namely $B$. americana, $B$. andersonii, $B$. bissettii, B. burgdorferi sensu stricto (s.s.), B. 
californiensis, B. carolinensis, B. garinii, Borrelia genomospecies 2, B. kurtenbachii, and B. mayonii [2-10]. Of these genospecies, B. americana, B. andersonii, $B$. bissettii, B. burgdorferi s.s., B. garinii, B. kurtenbachii, and $B$. mayonii are known to be pathogenic to humans and certain domestic animals $[9,11-14]$.

Blacklegged ticks feed on more than 125 North American vertebrates (avian, mammalian, reptilian) [15]. This ixodid tick has been collected from at least 81 bird species in the United States and Canada and, in particular, songbirds (Passeriformes) play a key role in the wide dispersal of I. scapularis larvae and nymphs. Biogeographically, larval and nymphal $I$. scapularis have been reported during spring migration on Neotropical songbirds as far north and as far west as Slave Lake, Alberta [16, 17]. As well, I. scapularis immatures have been recorded on passerine migrants in Saskatchewan, Manitoba, northern Ontario, southern Ontario, Quebec, New Brunswick, Nova Scotia, and Prince Edward Island [16-21]. Pertinent to the present study, passerine migrants provide an influx of bird-feeding ticks annually to the Kenora District.

Historically, Banerjee et al. [22] isolated $B$. burgdorferi s.l. from an I. scapularis female collected from a resident dog of Kenora, Ontario with no history of travel. Subsequently, Canadian tick researchers reported $B$. burgdorferi s.l.-positive $I$. scapularis on people and domestic hosts residing between Kenora and Clearwater Bay, and further north in the Kenora District [23]. In the upper Midwest, Turtinen et al. [24] reported an infection prevalence of $35.7 \%$ for B. burgdorferi s.l. in I. scapularis adults collected in Wisconsin.

The aim of this study was to determine if there is an established population of $I$. scapularis on Corkscrew Island and to determine the prevalence of B. burgdorferi s.l. in these ticks.

\section{Materials and Methods}

Study area. Corkscrew Island, Ontario $\left(49^{\circ} 40^{\prime}\right.$ $36^{\prime \prime} \mathrm{N}, 94^{\circ} 40^{\prime} 58^{\prime \prime} \mathrm{W}$ ) is located in the northern part of Lake of the Woods between Clearwater Bay and Kenora, Ontario (Figure 1). This 1064.7 ha, zigzag-shaped island is situated along the southern fringe of the Canadian Shield, which consists of Precambian igneous rock, and lies within the southernmost belt of the boreal forest. Geographically, this insular tract of land is $1.5 \mathrm{~km}$ from the mainland (on the east side). A grassy meadow extends over part of the core area, while a deciduous-coniferous forest covers much of the perimeter of the island. The predominant tree species include trembling aspen, Populus tremoides; bur oak, Quercus macrocarpa; red ash, Fraxinus pennsylvanica; black ash, Fraxinus nigra; white spruce, Picea glauca; black spruce, Picea mariana; and eastern white pine, Pinus strobus. Smaller arboreal shrubs include: American hazelnut, Corylus americana; Saskatoon berry, Amelanchier alnifolia; bittersweet, Celastrus scandens; and smooth rose, Rosa blanda. Poison ivy, Rhus radicans, is prevalent, and various grass species abound, especially in the central area of the island.

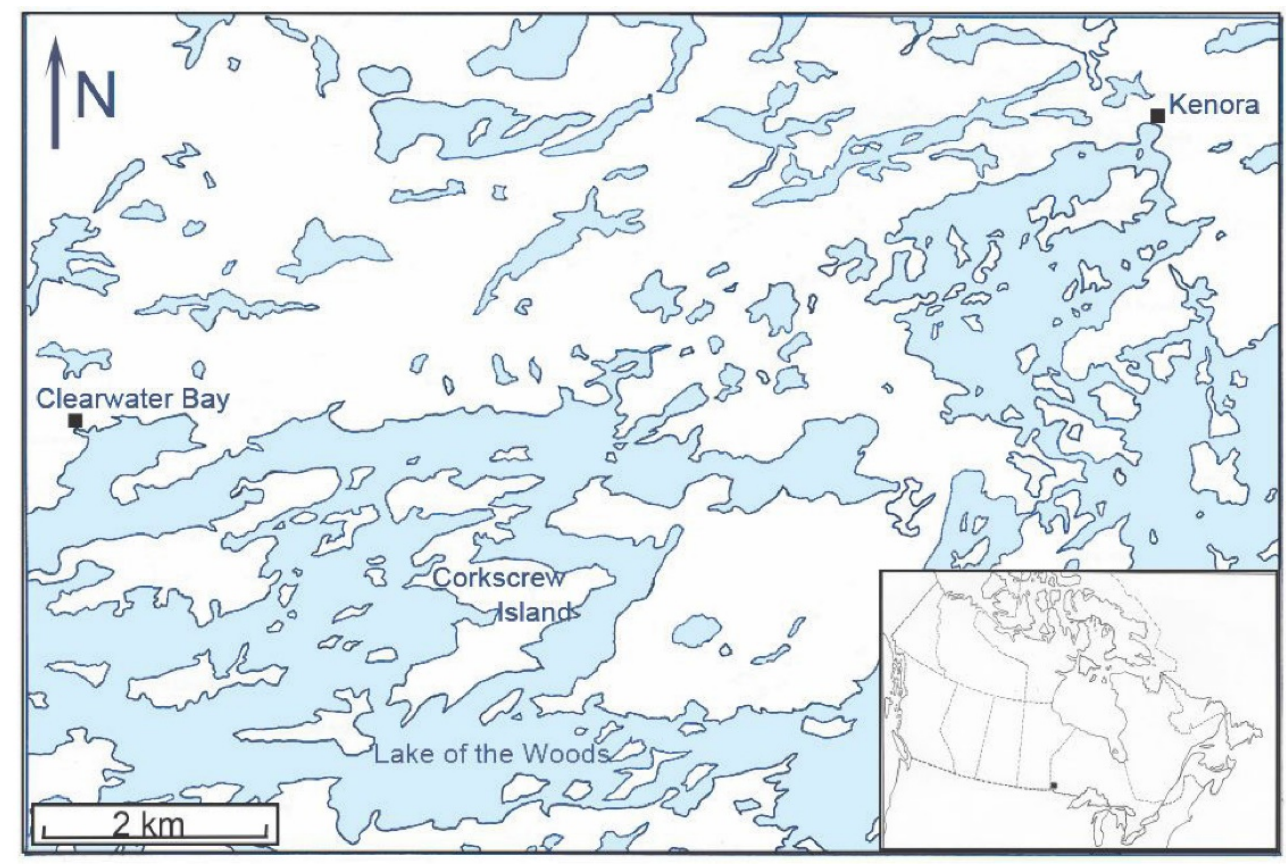

Figure 1. Map of the northern part of Lake of the Woods showing the geographic location of Corkscrew Island, Kenora District, Ontario. 
Large animals consist of white-tailed deer, Odocoileus virginianus; American black bear, Ursus americanus; and gray wolf, Canis lupus. Medium-sized animals include Canadian beaver, Castor canadensis; red fox, Vulpes vulpes; raccoon, Procyon lotor; and snowshoe hare, Lepus americanus. Small mammals comprise: deer mouse, Peromyscus maniculatus; meadow vole, Microtus pennsylvanicus; southern red-backed vole, Myodes gapperi; northern short-tailed shrew, Blarina brevicauda; eastern chipmunk, Tamias striatus; least chipmunk, Tamias minimus; and American red squirrel, Tamiasciurus hudsonicus.

Gallinaceous birds include Ruffed Grouse, Bonasa umbellus and Spruce Grouse, Falcipennis canadensis, whereas some of the prominent ground-foraging passerines include Song Sparrow, Melospiza melodia; Pine Grosbeak, Pinicola enucleator; Eastern Phoebe, Sayornis phoebe; and Blue Jay, Cyanocitta cristata.

Tick collection. Blacklegged tick adults were collected by flagging low-level vegetation during the spring and fall bimodal questing periods (spring 2014 to spring 2016) (Figure 2A, B). Nymphs were collected from the leaf litter by flagging around bur oaks during late May and early June. The habitats for flagging included open field (grass meadow), ecotone (woods edge), and open canopy (sparse trees). The flag cloth was made from a piece of sweatshirt fleece measuring $70 \mathrm{~cm}$ by $80 \mathrm{~cm}$. Ticks were removed from the flag with fine-pointed tweezers, and put in $8.5 \mathrm{~mL}$ polypropylene vials $(15.7 \mathrm{~mm} \times 74 \mathrm{~mm})$ with a label listing background information (i.e., geographical location, date collected). A 7-mm hole in the polyethylene push-cap (15.7 $\mathrm{mm}$ diameter) provided ventilation for the ticks. After the ticks were inserted, a piece of tulle netting was placed over the mouth of the vial before inserting the push-cap preventing ticks from escaping. The vial was placed in a self-sealing, double-zippered plastic bag with a slightly moistened section of paper towel, and sent in a bubble-pack envelope to the laboratory (JDS). A taxonomic key and re-description information were employed for morphological identification $[15,25]$.

We flagged leaf litter within a radius of $3 \mathrm{~m}$ from the trunks of mature bur oaks in both open canopy and ecotone areas for nymphs during the nymphal questing period (28 May 2016 - 19 June 2016) (Figure 2C).

In order to check winter hardiness, we set out live I. scapularis adults in a wooded area in October (2015) and collected them in April (2016). They were placed in vented polyethylene vials that were inserted in a vented, plastic canister $(63 \mathrm{~mm} \times 135 \mathrm{~mm})$. This container was covered with aluminum screen for mouse exclusion. The screened canister was then put in an open-ended wooden crate $(80 \mathrm{~mm} \times 125 \mathrm{~mm} \times$ $150 \mathrm{~mm}$ ) for hoof protection. A layer of leaves was placed over the overwinter box to reflect the surrounding leaf layer.

Spirochete detection. During Phase 1, we sent live ticks to the vector ecology and zoonotic diseases laboratory (JFA) for culturing. Live ticks were cultured in Barbour-Stoenner-Kelly (BSK) medium, and dead ticks were directly tested using DNA extraction and PCR testing. The DNA detection protocols have been described previously [26-28]. Although Persing et al. [26] used both the flagellin gene $(f l a)$ and the major outer surface protein A $(O s p A)$ gene, which is on the 49-kbp linear plasmid, we only employed the OspA gene in Phase 1 study. Appropriate negative and positive controls were used.

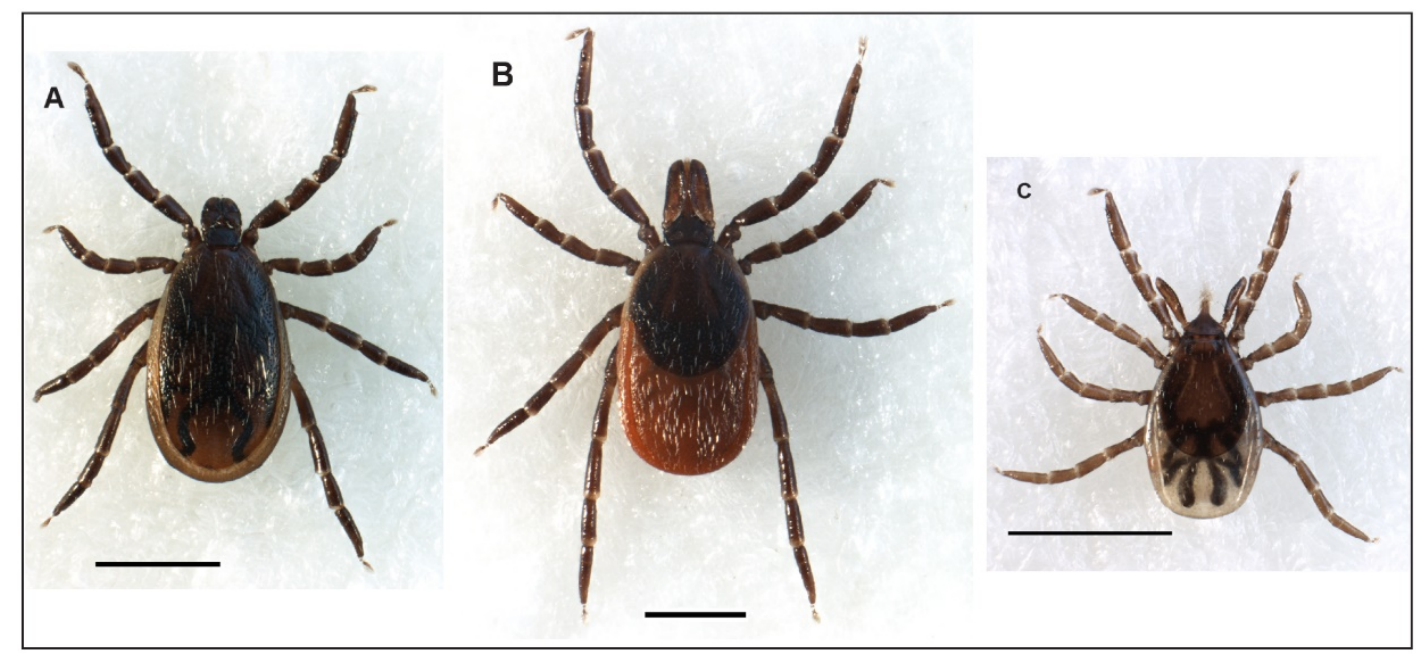

Figure 2. Blacklegged ticks, A) male, B) unfed female, and C) unfed nymph. Bar, 1 mm. Photo credit: Kellyn Hough 
For Phase 2, ticks were put in $94 \%$ ethyl alcohol and forwarded to the environmental epidemiology research laboratory (KLC). These ticks were PCR tested using primers of the flagellin $\mathrm{B}(\mathrm{flaB})$ gene and the 16S-23S r RNA intergenic spacer gene. For ticks collected in the latter part of Phase 2, we only used the $\mathrm{flaB}$ gene. The methodology is described in Scott et al. [29]. In Phase 2, the negative control consisted of nuclease-free TE buffer. In order to prevent DNA contamination, a positive control sample was not used. Amplicons of the 194-bp (base position 313 to 506) and the 206-bp (base position 532 to 737) of the $B$. burgdorferi s.l. flaB gene were obtained from four $I$. scapularis adults (14-5A192A-1, 14-5A197, 14-5A201A, 15-5A79A) using PCR1 and PCR2 primer sets, respectively.

For Phase 3, ticks were sent by courier to the biomolecular laboratory (JEF). These ticks were PCR tested using primers of the flagellin $(f l a)$ gene to detect $B$. burgdorferi s.l., and the procedures are described elsewhere [30, 31].

The infection prevalence of B. burgdorferi s.l. in I. scapularis adults was calculated by dividing the total number of B. burgdorferi s.l.-infected ticks by the total number of $I$. scapularis males and females tested. Likewise, the same calculations apply to nymphs.

Nucleotide sequences. In phase 2, DNA sequences of the flaB gene of B. burgdorferi s.l. amplicons were deposited in the GenBank database with accession numbers: KT807493, KT827334 for tick 14-5A192-1; KT807495, KT827328 for tick 14-5A197; KT807496, KT827329 for tick 14-5A201A; and KX011448 for tick 15-5A79A. In phase 3, nucleotide sequences for the fla gene were obtained from an unfed nymph (16-5A36A) and an unfed female (16-5A10F4), and the GenBank accession numbers are KX459422 and KX459423, respectively.

\section{Results}

Tick collection. All host-feeding life stages (larvae, nymphs, adults) of I. scapularis were collected from Corkscrew Island. In total, 130 I. scapularis adults were gathered by flagging low-level vegetation during a 3-yr period (Figure 2A, B). In addition, we gleaned 15 unfed, questing I. scapularis nymphs from the forest floor by flagging leaf litter contiguous to bur oaks during the late spring (28 May to 19 June 2016) (Figure 2C). An I. scapularis larva was collected from a juvenile deer mouse, which captured in a domestic mouse trap on 3 September, 2016; several unfed, questing larvae were also obtained by flagging leaf litter around bur oaks in September and early October 2016.

In addition, an I. scapularis female was removed from an adult human female in mid-October 2013 and an I. scapularis male was detached from an adult human male in May 2016; these adult ticks were both attached to seasonal cottagers on Corkscrew Island.

We found that the ecotone and open canopy had the most I. scapularis ticks. During flagging, we found a close correlation between bur oak and questing $I$. scapularis. We estimate that $90 \%$ of the I. scapularis nymphs and adults were collected within $3 \mathrm{~m}$ of the trunks of bur oaks.

For the overwinter survival study (2015-2016), 13 $(93 \%)$ of 14 I. scapularis males and females overwintered successfully in an outdoor wooded area (a single female died). Because we have collected $I$. scapularis adults, each spring, for 3 years, we have documented the overwintering of I. scapularis adults at this site for 3 consecutive winters.

A sample of 20 adult American dog ticks, Dermacentor variabilis, was collected but not tested for B. burgdorferi s.l. because this tick species is not a competent vector of Lyme disease spirochetes. Ecologically, we found that American dog ticks are sympatric with blacklegged ticks on Corkscrew Island. Two unfed nymphs of the rabbit tick, Haemaphysalis leporispalustris, were collected from the leaf litter by flagging in late spring. As well, several $H$. leporispalustris larvae were collected by flagging leaf litter in late summer.

Spirochete detection. Of $130 \mathrm{I}$. scapularis adults collected, $60(73 \%)$ of 82 were positive for $B$. burgdorferi s.l. (Table 1). Overall, flagging was conducted for 18.0 hours, which averaged $7.2 \mathrm{I}$. scapularis males and females per hour (range, 3 to 28 adults/h). Using DNA sequencing, B. burgdorferi s.s. was characterized. A live culture of B. burgdorferi s.l. was obtained from one of the I. scapularis females (14-5A134B) during Phase 1 (JFA); however, it was not sent for DNA sequencing.

Table 1. Detection of B. burgdorferi s.l. in I. scapularis adults collected by flagging on Corkscrew Island, Ontario, 2014-2016

\begin{tabular}{lll}
$\begin{array}{l}\text { Collection } \\
\text { period }\end{array}$ & $\begin{array}{l}\text { No. of } \\
\text { ticks tested }\end{array}$ & $\begin{array}{l}\text { Ticks testing } \\
\text { PCR-pos. (\%) }\end{array}$ \\
\hline Spring 2014 & 4 & $3(75)$ \\
Fall 2014 & 15 & $12(80)$ \\
Spring 2015 & 35 & $23(66)$ \\
Fall 2015 & 10 & $7(70)$ \\
Spring 2016 & 18 & $15(83)$ \\
Total & 82 & $60(73)$
\end{tabular}

Of the I. scapularis nymphs tested, 6 (43\%) of 14 were positive for $B$. burgdorferi s.l. This infection prevalence is the highest ever reported for I. scapularis nymphs in Canada. Since transovarial transmission of B. burgdorferi s.l. in I. scapularis is not present, larvae 
were not tested for B. burgdorferi s.l. The collection of all host-feeding stages (larva, nymph, adult) of $I$. scapularis underpins the presence of an established population of I. scapularis on Corkscrew Island. In addition, the two $H$. leporispalustris nymphs were tested for B. burgdorferi s.l., but were negative.

\section{Discussion}

Significant epidemiological findings. We document a hyperendemic area for Lyme disease on Corkscrew Island, and validate that I. scapularis ticks overwinter successfully on this island. At the same time, we report the most northern Lyme disease endemic area in Ontario. All three host-feeding life stages were collected in a single year, and these collections confirm an established population of blacklegged ticks. The infection prevalence for adult B. burgdorferi s.l. was $73 \%$; this is the highest infection prevalence reported anywhere in Canada. Additionally, $43 \%$ of I. scapularis nymphs were infected with Lyme disease spirochetes; this is the highest nymphal infection rate for I. scapularis reported in Canada. Our findings show that people frequenting Corkscrew Island should take precautions to avoid contracting Lyme disease and associated tick-borne diseases.

Establishment on Corkscrew Island of $I$. scapularis. There are several possible ways that $B$. burgdorferi s.l.-infected I. scapularis could have become established on Corkscrew Island. Geographically, the closest point between the island and the mainland is $1.5 \mathrm{~km}$ (Figure 1). White-tailed deer are good swimmers, and can easily make the crossing; in fact, a Sitka black-tailed deer, Odocoileus hemionus sitkensis, was reported to have swum $22.5 \mathrm{~km}$ from one island to another island along Alaska's southeastern coast [32]. In late fall and spring, white-tailed deer have hollow hair, which adds buoyancy for long-distance crossings. When Lake of the Woods freezes in late December and early January for several months each winter, large mammals (i.e., white-tailed deer, black bear, gray wolves) can cross the ice from the mainland, unhindered. However, I. scapularis ticks are not questing in this frigid weather when sub-zero temperatures and snow cover prevail. Therefore, $I$. scapularis would not be introduced during the winter. With an overwinter survival of $93 \%$ at this site, we show that I. scapularis is well adapted to withstand cold climes. Black bears are also good swimmers, and have been seen swimming to Corkscrew Island. Black bears could, likewise, bring I. scapularis ticks to the island [33]. Additionally, a person with a companion animal, such as a dog, could introduce all 3 host-feeding life stages of $I$. scapularis. If a gravid female is introduced by a transient mammal from the mainland, it could oviposit in the leaf litter on Corkscrew Island; however, the progeny would not be infected with B. burgdorferi s.l. Transovarial transmission of B. burgdorferi s.l. is not present in $I$. scapularis ticks. Alternatively, a heavily-infested songbird with I. scapularis immatures could start an established population of I. scapularis [34]. Since songbirds transport $B$. burgdorferi s.l.-infected $I$. scapularis immatures, it is most likely avian hosts were the original mode of establishing a Lyme disease endemic area on Corkscrew Island.

A high prevalence of $B$. burgdorferi s.l. in an established population of I. scapularis indicates that Lyme disease spirochetes have likely been present for many years. For example, this phenomenon is borne out at Point Pelee National Park, Ontario, at the southern tip of Canada; there, Banerjee et al. [35] found that the B. burgdorferi s.l. infection prevalence in 1997 was nil. Later, Thorndyke [36] revealed that the prevalence of B. burgdorferi s.l. in I. scapularis adults shifted gradually and incrementally from $5.5 \%$ (2005) to 27.4 (2012). Although there was a fluctuation of $B$. burgdorferi s.l. presence from year to year, there was an increase in infection prevalence with time. Historically, Watson and Anderson [37] provide the first account of an established population of $I$. scapularis in Canada; field studies in 1972 and 1973 revealed all host-feeding life stages of I. scapularis at Long Point, Ontario. Because the infection prevalence (73\%) of B. burgdorferi s.l. in I. scapularis adults on Corkscrew Island is higher than Long Point, Ontario $(60 \%)$, we suggest that the I. scapularis breeding colony on Corkscrew Island pre-dates the one at Long Point, but was overlooked.

There is anecdotal evidence that patients have contracted Lyme disease on Corkscrew Island and the surrounding area. These patients developed multiple clinical symptoms indicative of Lyme disease, including progressive arthritis, neurological deficits, and profound fatigue. Of medical significance, Scrimenti [38] described an erythematous rash on a patient (a physician), who was bitten by a tick while grouse hunting in the fall of 1969 in Wisconsin; he represents the first recognized case of Lyme disease in North America in modern history. The attached tick was most likely an I. scapularis female because American dog ticks (D. variabilis) do not quest in October in this geographic area.

Based on accumulated degree-days and the placement of I. scapularis ticks in outdoor housing units, Lindsay et al. [39] postulated that the climate in the Kenora District, Ontario was not warm enough for I. scapularis to survive and become an established population. These researchers stated that I. scapularis would be limited to areas of Ontario south of an 
imaginary line between North Bay and Thunder Bay, and westward to the Rainy River District, which is south of Kenora. Conversely, our study clearly shows that there are adequate degree-days for I. scapularis to thrive on Corkscrew Island. In the present study, blacklegged tick adults were winter hardy for 3 consecutive winters $(2014,2015,2016)$. What was once considered by some researchers as a hostile environment for I. scapularis has turned out to be one of the most hyper endemic areas for Lyme disease in Canada.

Blacklegged ticks have an innate ability to withstand weather extremes [40]. Based on historical annual weather data, the maximum extreme high at Kenora was recorded at $36^{\circ} \mathrm{C}$, whereas the minimum extreme low was $-44^{\circ} \mathrm{C}$. The normal accumulated snow cover is $22 \mathrm{~cm}$ (Environment Canada). Blacklegged ticks are adapted to these conditions because they have antifreeze-like compounds (glycoproteins) in their bodies [41]. Since sub-zero, ambient air temperatures prevail at Corkscrew Island throughout the winter, I. scapularis can survive in the leaf litter under an insulating blanket of snow. During hot summer days, they descend into the cool, moist leaf litter, and re-hydrate. Based on our studies, harsh ambient air temperatures are not a limiting factor in the survival of I. scapularis in the Kenora District.

High prevalence of $B$. burgdorferi s.l. On Corkscrew Island, there are several biotic factors that could contribute to the exceptionally high prevalence of B. burgdorferi s.l. in I. scapularis. Small mammals, which are reservoir-competent hosts for B. burgdorferi s.l. include: deer mice [42, 43], northern short-tailed shrew [44, 45], eastern chipmunks [46, 47], meadow voles [48], and southern red-backed voles [49]. Although white-tailed deer are incompetent reservoirs of $B$. burgdorferi s.l. [50], they act as amplifying hosts of I. scapularis ticks, and support their reproduction. Alternate hosts for I. scapularis adults include: woodchuck, American red squirrel, raccoon, red fox, gray wolf, and American black bear $[51$, 52]. Blacklegged tick males and females commonly mate on deer and, when females become fully engorged, they drop from their hosts into the leaf litter of tick-conducive habitats. Because blacklegged ticks are subject to desiccation, they favour sheltered woodlands and shady ecotones, and employ ambush strategies to parasitize their hosts.

When small mammals transect the microhabitat where I. scapularis females have deposited their eggs, they can become highly parasitized by hundreds of host-seeking larvae [34]. If these small mammals are already spirochetemic, they can transmit B. burgdorferi s.l. to the larvae during feeding and, subsequently, these replete larvae will transstadially pass Lyme disease spirochetes to nymphs during the larva-nymph moult. During the next blood meal, these nymphs can transmit spirochetes to the next hosts. Since white-footed mice, Peromyscus leucopus, are not present on Corkscrew Island, the high prevalence of $B$. burgdorferi s.l. in I. scapularis elucidates the fact that this small mammal is not needed to maintain a high level of borrelial endemicity. With such a high prevalence of $B$. burgdorferi s.l. in I. scapularis adults on Corkscrew Island, we found that the enzootic transmission cycle of $B$. burgdorferi s.l. is very efficient.

Questing activity of blacklegged ticks tied to oaks. In the present study, approximately $90 \%$ of the I. scapularis ticks were collected within $3 \mathrm{~m}$ of the trunks of bur oaks. Ostfeld et al. [53] found that whenever there is an abundant acorn crop, the number of mice significantly increased the following year and, likewise, the number of I. scapularis nymphs on white-footed mice strengthened. Large mast production provides highly nutritious food for both cricetid (i.e., deer mice) and sciurid (i.e., eastern chipmunks) rodents and white-tailed deer. Gravid females frequently drop from their hosts (i.e., white-tailed deer) in juxaposition to bur oaks. Stafford [54] discovered that I. scapularis larvae normally travel no more than $40 \mathrm{~cm}$, but can crawl up to $2 \mathrm{~m}$ from the egg-laying site. In addition, Carroll [55] collected larvae on the trunks of oaks to a height of $2 \mathrm{~m}$, which indicates that gravid females frequently drop from their hosts near oak trees. When we mapped the position of bur oaks and the sites where I. scapularis adults and nymphs were collected, we found that there was a direct correlation between these two biotic variables. Not only do bur oaks act as a source of high energy acorns, they provide a tick-conducive habitat for I. scapularis. As well, bur oaks act as a communal hub for deer and small mammals, and provide high-energy food for deer and reservoir-competent rodents. Moreover, other arboreal plants, such as American hazelnuts and Saskatoon berries, provide nutrition for rodents.

Blacklegged ticks use chemosensilla (sense organs) to detect ammonia, carbon dioxide, lactic acid, and various phenols [56]. These compounds play a vital role in finding their hosts. In particular, blacklegged ticks are attracted to host scent trails and the source of ammonia, which is generated by animal by-products (e.g., urine, faeces). Another tick attractant, lactic acid, is produced by mammalian hosts during normal metabolism and exercise. Phenols are present in urine, sweat, body odor, and estrogen hormones (i.e., estradiol), and are also released from decomposing leaf litter. Moreover, carbon dioxide from exhaled breath stimulates ticks, 
and activates front leg flailing. Tick chemosensilla continue to be active as long as there is a chance of parasitizing an approaching host [56]. In the spring, gravid females commonly lay their eggs in the leaf litter in close proximity to bur oaks on Corkscrew Island, and start a new generation of I. scapularis.

When we flagged the leaf litter in the vicinity of bur oaks, we found that blacklegged tick nymphs were actively questing in late May through June. After nymphs parasitize a host and obtain a blood meal, they will moult to adults in 5 to 9 weeks. If they are not successful in parasitizing a host during the summer, they will overwinter and start host-seeking in the spring. Based on the presence of nut-producing oaks and highly-efficient, reservoir-competent hosts, Corkscrew Island has natural amenities (i.e., ideal microclimate, suitable hosts) to support an established population of I. scapularis. Moreover, the abundance of reservoir-competent hosts on Corkscrew Island helps to reinforce and sustain the enzootic transmission of B. burgdorferi s.l.

Presence of $I$. scapularis immatures on Corkscrew Island. In this study, we focused on the collection of $I$. scapularis adults because they are the easiest to collect and they have had two previous blood meals and represent the highest level of $B$. burgdorferi s.l. infectivity. Over the 3-year study period, we allowed enough time for this tick species to complete its entire life cycle. Rand et al. [57] found that when white-tailed deer, which are reservoir-incompetent hosts, were completely and permanently eliminated from Monhegan Island, 16 $\mathrm{km}$ off Maine's coast, the B. burgdorferi s.l. infection prevalence in I. scapularis adults dropped from $75 \%$ to $29 \%$ in four years. Based on their findings, we can hypothesize that I. scapularis larvae and nymphs are feeding on small mammals with a high prevalence of spirochete infection on Corkscrew Island, and that these ixodid immatures become infected with $B$. burgdorferi s.l. from spirochetemic hosts. Since unfed $I$. scapularis nymphs had infection prevalence of $43 \%$, terrestrial small mammals are probably acting as the reservoirs for spirochetal infection. Because both $I$. scapularis nymphs and adults on Corkscrew Island have such an elevated prevalence of B. burgdorferi s.l., we have substantial evidence that Lyme disease spirochetes are cycling enzootically within this highly endemic focus.

Small mammals are maintenance hosts and birds are incidental hosts in the enzootic cycle of $B$. burgdorferi s.l. [44]. Without larvae and nymphs feeding on highly-infected B. burgdorferi s.l. reservoirs, I. scapularis adults would not be able to acquire high infectivity, namely $73 \%$, in our study. Scott and Durden [21] found that bird-feeding I. scapularis nymphs collected in central and eastern Canada had an infection prevalence of $35 \%$. Most significantly, when replete B. burgdorferi s.l.-infected I. scapularis nymphs drop to the leaf litter from avian hosts, they do not double their infection prevalence, and would not have obtained the infection prevalence of $73 \%$. Since songbird-derived I. scapularis immatures only generate a $B$. burgdorferi s.l.-infection prevalence of $35 \%$ or less, we conclude that I. scapularis adults with an infection prevalence of $73 \%$ originate from terrestrial reservoir hosts on Corkscrew Island. In order for a high $B$. burgdorferi s.l. prevalence to be maintained, there must be large mammals for $I$. scapularis females to acquire blood meals, and males and females to mate. White-tailed deer, black bears, raccoons, red fox, and gray wolves act as suitable hosts on Corkscrew Island to facilitate mating of $I$. scapularis adults and propagate a new generation of $I$. scapularis ticks [33]. In addition, unfed nymphs are actively questing in late June for highly efficient, reservoir-competent, small- and medium-sized hosts on Corkscrew Island. With respect to spirochete infection, an unfed nymph is one and the same as a replete larva; the only difference, is that it has gone through the larva-nymph moult. Likewise, males and unfed females are analogous to fully engorged nymphs; only, they have advanced through the nymph-adult moult. With the collection of all 3 host-feeding life stages in a single year, we are assured that an established population of I. scapularis is present on Corkscrew Island. Moreover, our findings underpin the fact that this tick species is cycling through all life stages (egg, larva, nymph, adult). Now that we have studied I. scapularis for three years, and have allowed it to complete it's 2-year life cycle, we fulfil the criteria for an estabished population of I. scapularis on Corkscrew Island.

Transportation of $I$. scapularis to Corkscrew Island by songbirds. Migratory songbirds play a key role in the wide dispersal of I. scapularis larvae and nymphs. Peak northward songbird migration in Canada occurs during May and early June, and this time of year coincides with the peak questing period of I. scapularis nymphs. When Neotropical and southern-temperate passerines make landfall at food-rich stopovers located along their migration routes, they can be parasitized by I. scapularis larvae and nymphs. Along the flight path, tick-infested songbirds could release I. scapularis immatures on Corkscrew Island and the surrounding islands and on the mainland. Anderson \& Magnarelli [44] reported 19 I. scapularis nymphs on an American Robin, Turdus migratorius, and 21 larvae on a Swamp Sparrow, Melospiza georgiana. If passerines are highly infested with I. scapularis immatures, they can initiate new foci 
of I. scapularis [34]. These bird-feeding ticks can be infected with B. burgdorferi s.l. and other tick-associated pathogens. Passerines may also acquire I. scapularis immatures on Corkscrew Island and transport them to the surrounding islands and the mainland.

En route to the boreal forest, passerines widely disperse Lyme disease vector ticks across Canada during northbound spring migration [16-21, 58-63]. Long-distance migrants transport Neotropical ticks to Canada from as far south as Brazil [61-63]. Notably, Scott and Durden [21] found that 35\% of the $I$. scapularis nymphs collected from songbirds in eastern and central Canada were infected with B. burgdorferi s.l. Since the infection prevalence in the I. scapularis adults on Corkscrew Island is double the level of infection in incoming replete, songbird-transported $I$. scapularis nymphs, we suggest that this tick population has a long history of being established for decades prior to 1972 in this northern locality.

Prevention strategies to minimize I. scapularis. Several attempts have been made in North America to minimize the presence of I. scapularis. When white-tailed deer were extirpated on Monhegan Island, Maine, the incidence of I. scapularis was reduced but not eliminated [57]; songbirds continue to introduce I. scapularis larvae and nymphs annually. On Corkscrew Island, birds can re-introduce $I$. scapularis immatures and, similarly, deer parasitized by I. scapularis adults, can swim to the island. Controlled burns have temporally reduced the number of I. scapularis ticks, but the tick population replenished itself within three years [64-66]. To survive, ticks hide in protective sites, such as topsoil cracks, earthworm holes, and rotten logs. In order to make the environment less conducive to ticks, seasonal cottage owners on Corkscrew Island should keep grass cut and leaves raked [67]. Timely acaricide sprays have helped to reduce the occurrence of $I$. scapularis, but have failed to completely eliminate $I$. scapularis colonies [68]. On Corkscrew Island, bur oaks should be cut down around cottages and outbuildings to deter deer and rodents. Compost bins exacerbate the tick problem because they attract rodents infested with ticks. At the end of the day, cottagers and visitors should do a full body tick check. If a tick is found attached, take a close-up, digital, colored photograph to document the tick bite. The attached tick should be removed promptly with fine-pointed stainless steel tweezers. Grip the hypostome (barbed mouthpart) at the surface of the skin, and gently and firmly pull tick straight out. The tick should be kept for identification and PCR testing. The tick can be preserved in a tightly sealed vial of rubbing alcohol or ethanol.

Human and zoonotic health considerations.
Lyme disease is a zoonotic spirochetosis that is typically transmitted to humans and other vertebrates by ixodid ticks. Transmission normally occurs 24-48 hours after tick attachment [68]; however, Cook [69] reports transmission of Lyme disease spirochetes in less than 16 hours, especially if the tick salivary glands are infected. Notably, other tick-borne pathogens can be transmitted much quicker. For instance, Powassan virus can be transmitted in less than 15 minutes [70]. After transmission, Lyme disease spirochetes progress and circulate throughout the body, and can simultaneously affect many organs and tissues. Patients may have an erythematous rash (i.e., bull's-eye, homogenous, atypical, erythema multiforme); however, $42 \%$ or less, have a rash [71-74]. As this multisystem disease advances, patients can present with a diverse array of symptoms, including fatigue, flu-like symptoms, arthritis, inflammation, radicular pain, peripheral neuropathy, and cognitive dysfunction [75]. Spirochetes evade host defenses, locate intracellularly, and form more resistant forms [76]; they also attach to, invade, and kill B and T lymphocytes [77]. As the zoonosis advances, spirochetes produce neurotoxins that induce inflammatory cytokines (i.e., interleukin 1 , interleukin 6, TNF-alpha) [78, 79], and can result in mitochondrial dysfunction, oxidative stress, and physical and hormonal abnormalities [79, 80]. If left untreated or inadequately treated, B. burgdorferi s.s. will sequester and persist in deep-seated tissue, including brain [81-83], bone [84], collagenous tissues (ligaments, tendons) [85, 86], eye [87], glial and neuronal cells [88, 89], muscle [90], and fibroblasts/scar tissue [91]. Since B. burgdorferi s.s. is pleomorphic, treatment must take into account diverse forms (i.e., spirochetes, round bodies, blebs, granules); collectively, they form slime-coated, polysaccharide matrices, called biofilms [92]. Persister cells, which survive antimicrobials, must be recognized in refractory cases [93]. Lyme disease, which often manifests as a chronic infection, can sometimes be fatal $[71,81,94]$. Since spirochetes lodge in human testicles, semen, and vaginal secretions, $B$. burgdorferi s.s. can be sexually transmitted [95, 96]. Early treatment is very important; delayed treatment of Lyme disease may be long and difficult [97, 98].

In conclusion, we collected all 3 host-feeding life stages of I. scapularis, and provide the first authentic report of an established population on Corkscrew Island, Kenora District. We document the northernmost known breeding colony of I. scapularis in Ontario. This northerly hyperendemic area for Lyme disease has a $B$. burgdorferi s.l. infection prevalence of $73 \%$, and constitutes the highest known infection prevalence for B. burgdorferi s.l. in all of 
Canada. Our study reveals that white-footed mice are not the primary reservoirs of B. burgdorferi s.l. at this site or possibly at other sites in North America. Not only is there a well-established population of $I$. scapularis on Corkscrew Island, ticks are infected with B. burgdorferi s.s., which is pathogenic to humans and certain domestic animals. Health-care providers need to be aware that anyone visiting Corkscrew Island during the temperate months can contract Lyme disease. Public health officials are legally obligated to warn the public that this Lyme disease hotspot poses a major public health risk.

\section{Acknowledgments}

We thank a local volunteer who collected ticks and a wildlife biologist for background information. We are indebted to Elizabeth E. Alves, Angela Bransfield, and Kenny Lou for technical assistance. We are grateful to Kellyn Hough and Monica Young for taking the photographs of the I. scapularis ticks and to John Ward for providing computer graphics. Funding for this tick study was supported in part by Lyme Ontario.

\section{Competing Interests}

The authors have declared that no competing interest exists.

\section{References}

1. Burgdorfer W, Barbour AG, Hayes SF, et al. Lyme disease-a tick-borne spirochetosis? Science 1982; 216: 1317-1319. doi:10.1126/science.7043737

2. Baranton G, Postic D, Saint Girons I, et al. Delineation of Borrelia burgdorferi sensu stricto, Borrelia garinii sp. nov. and group VS461 associated with Lyme borreliosis. Int J Syst Bacteriol. 1992; 42: 378-383. doi: 10.1099/00207713-42-3-378

3. Marconi RT, Liveris D, Schwartz I. Identification of novel insertion elements, restriction fragment length polymorphism patterns, and discontinuous $23 \mathrm{~S}$ rRNA in Lyme disease spirochetes: phylogenetic analysis of rRNA genes and their intergenic spacers in Borrelia japonica sp. nov. and genomic group (Borrelia andersonii sp. nov.) isolates. J Clin Microbiol. 1995; 33: 2427-2434. http://www.researchgate.net/publication/15705144_4

4. Postic D, Ras NM, Lane RS, et al. Expanded diversity among Californian Borrelia isolates and description of Borrelia bissettii sp. nov. (formerly Borrelia group DN127). J Clin Microbiol. 1998; 36: 3497-3504. http://www.ncbi.nlm.nih.gov/pmc/articles/PMC105228/

5. Smith RP, Muzaffar SB, Lavers J, et al. Borrelia garinii in seabird ticks (Ixodes uriae), Atlantic coast, North America. Emerg Infect Dis. 2006; 12: 1909-1912. doi:10.3201/eid1212.060448

6. Rudenko N, Golovchenko M, Grubhoffer L, et al. Borrelia carolinensis sp. nov, a new $\left(14^{\text {th }}\right)$ member of the Borrelia burgdorferi sensu lato complex from southeastern region of the United States. J Clin Microbiol. 2009; 47: 134-141. doi: 10.1099/ijs.0.021436-0

7. Rudenko N, Golovchenko M, Lin T, Gao L, et al. Delineation of a new species of the Borrelia burgdorferi sensu lato complex, Borrelia americana sp. nov. J Clin Microbiol. 2009; 47: 3875-3880. doi: 10.1128/JCM.01050-098

8. Margos G, Hojgaard A, Lane RS, et al. Multilocus sequence analysis of Borrelia bissettii strains from North America reveals a new Borrelia species, Borrelia kurtenbachii. Ticks Tick Borne Dis. 2010; 1: 151-158. doi: 10.1016/j.ttbdis.2010.09.002

9. Pritt BS, Mead PS, Hoang Johnson DK, et al. Identification of a novel pathogenic Borrelia species causing Lyme borreliosis with unusually high spirochaetaemia: a descriptive study. Lancet Infect Dis. 2016; 16: 556-564. http://dx.doi.org/10.1016/S1473-3099(15)00464-8. Corrections: Lancet Infect Dis. 2016; 16. http://dx.doi.org/10.1016/S1473-3099(16)30065-2

10. Scott JD. Borrelia mayonii: prying open Pandora's box of spirochetes. Lancet Inf Dis. 2016; 16: 637. http://dx.doi.org/10.1016/S1473-3099(16)30053-6

11. Girard YA, Fedorova N, Lane RS. Genetic diversity of Borrelia burgdorferi and detection of B. bissettii-like DNA in serum of north-coastal residents. J Clin Microbiol. 2011; 49: 945-954. doi: 10.1128/JCM.01689.10
12. Clark KL, Leydet B, Hartman S. Lyme borreliosis in human patients in Florida and Georgia, USA. Int J Med Sci. 2013; 10: 915-931. doi:10.7150/ijms.6273

13. Rudenko N, Golovchenko M, Vancová M, et al. Isolation of live Borrelia burgdorferi sensu lato spirochetes from patients with undefined disorders and symptoms not typical for Lyme borreliosis. Clin Microbiol Infect. 2016; 22: 267.e9-267.e15. doi:10.1016/j.cmi.2015.11.009

14. Golovchenko M, Vancová M, Clark KL, et al. A divergent spirochete strain isolated from a resident of the southeastern United States was identified by multilocus sequence typing as Borrelia bissettii. Parasit Vectors. 2016; 9: 68. doi: 10.1186/S13071-016-1353-4

15. Keirans JE, Hutcheson HJ, Durden LA, et al. Ixodes (Ixodes) scapularis (Acari: Ixodidae): redescription of all active stages, distribution, hosts, geographical variation, and medical and veterinary importance. J Med Entomol. 1996; 33: 297-318. http://www.ncbi.nlm.nih.gov/pubmed/8667375

16. Scott JD, Fernando K, Banerjee SN, et al. Birds disperse ixodid (Acari: Ixodidae) and Borrelia burgdorferi-infected ticks in Canada. J Med Entomol. 2001; 38: 493-500. doi:10.1603/0022-2585-38.4.493

17. Morshed MG, Scott JD, Fernando K, et al. Migratory songbirds disperse ticks across Canada, and first isolation of the Lyme disease spirochete, Borrelia burgdorferi, from the avian tick, Ixodes auritulus. J Parasitol. 2005; 91: 780-790. doi:10.1645/GE-3437.1

18. Ogden $\mathrm{NH}$, Lindsay RL, Hanincová $\mathrm{K}$, et al. Role of migratory birds in introduction and range expansion of $I$. scapularis ticks and of Borrelia burgdorferi and Anaplasma phagocytophilum in Canada. Appl Environ Microbiol. 2008; 74: 1780-1790. doi:10.1128/AEM.01982-07. Erratum: Appl Environ Microbiol. 2008; 74: 3919. http://dx.doi.org/10.1128/AEM.00857-08

19. Scott JD, Lee MK, Fernando K, et al. Detection of Lyme disease spirochete, Borrelia burgdorferi sensu lato, including three novel genotypes in ticks (Acari: Ixodidae) collected from songbirds (Passeriformes) across Canada. J Vect Ecol. 2010; 35: 124-139. doi:10.1111/j.1948.7134.2010.00068.x

20. Scott JD, Anderson JF, Durden LA. Widespread dispersal of Borrelia burgdorferi-infected ticks collected from songbirds across Canada. J Parasitol. 2012; 98: 49-59. doi: 10.1645/GE-2874.1

21. Scott JD, Durden LA. New records of the Lyme disease bacterium in ticks collected from songbirds in central and eastern Canada. Int J Acarol. 2015; 41: 241-249. http://dx.doi.org/10.1080/01647954.2015.1038301

22. Banerjee SN, Christensen CI, Scott JD. Isolation of Borrelia burgdorferi on mainland Ontario. Can Com Dis Rep. 1995; 21: 85-86. www.ncbi.nlm.nih.gov/pubmed/762054

23. Morshed MG, Scott JD, Fernando K, et al. Distribution and characterization of Borrelia burgdorferi isolates from Ixodes scapularis and presence in mammalian hosts in Ontario, Canada. J Med Entomol. 2006; 43: 762-773. http://dx.doi.org/jmedent/43.4.762

24. Turtinen LW, Kruger AN, Hacker MM. Prevalence of Borrelia burgdorferi in adult female ticks (Ixodes scapularis), Wisconsin 2010-2013. J Vect Ecol. 2015; 40: 195-197. doi: 10.1111/jvec.12152

25. Keirans JE, Clifford CM. The genus Ixodes in the United States: a scanning electron microscope study and key to the adults. J Med Entomol. 1978 (Suppl 2): 149. doi:10.1093/jmedent/15.suppl2.1

26. Persing DH, Telford III SR, Spielman A, et al. Detection of Borrelia burgdorferi infection in Ixodes dammini ticks with the polymerase chain reaction. J Clin Microbiol. 1990; 28: 566-572. http://www.ncbi.nlm.nih.gov/pubmed/1969867

27. Persing DH, Telford SR, Rys PN, et al. Detection of Borrelia burgdorferi DNA in museum specimens of Ixodes dammini ticks. Science 1990; 249: 1420-1423. doi:10.1126/science2402635

28. Scott JD, Anderson JF, Durden LA. First detection of Lyme disease spirochete Borrelia burgdorferi in ticks collected from a raptor in Canada. J Vet Sci Med Diagn. 2013; 2: 4. http://dx.doi.org/10.4172/2325-9590.1000123

29. Scott JD, Anderson JF, Durden LA, et al. Ticks parasitizing gallinaceous birds in Canada and first record of Borrelia burgdorferi-infected Ixodes pacificus (Acari: Ixodidae) from California Quail. Syst Appl Acarol. 2016; 12: 1-12. http://doi.org/10.11158/saa/21.1.1

30. Foley J, Piovia-Scott J. Vector biodiversity did not associate with tick-borne pathogen prevalence in small mammal communities in northern and central California. Ticks Tick Borne Dis. 2014; 5: 299-304. doi: 10.1016/j.ttbdis.2013.12.003

31. Scott JD, Foley JE. Detection of Borrelia americana in the avian coastal tick, Ixodes auritulus (Acari: Ixodidae), collected from a bird captured in Canada. Open J An Sci. 2016; 6: 207-216. http:/ /dx.doi.org/10.4236/ojas.2016.63027

32. Rue LL III. The deer of North America. 6th edition. Crown, New York: Outdoor Life Books; 1981.

33. Anderson JF. Mammalian and avian reservoirs for Borrelia burgdorferi. Ann N Y Acad Sci. 1988; 539: 180-191. doi:10.1111/j.1749-6632.1988.tb31852.x

34. Scott JD, Scott CM, Anderson JF. The establishment of a blacklegged tick population by migratory songbirds in Ontario, Canada. J Vet Sci Med. 2014; 2: 5. http://dx.doi.org/10.13188/2325-4645.1000005

35. Banerjee SN, Morshed MG, Scott JD. Epizootiology of the Lyme disease spirochete, Borrelia burgdorferi in blacklegged ticks, Ixodes scapularis and small mammals at Point Pelee National Park. Point Pelee National Park Library, Parks Canada, Leamington, Ontario. 2000.

36. Thorndyke R. Blacklegged tick (Ixodes scapularis) collection for testing for the Lyme disease bacteria (Borrelia burgdorferi) at Point Pelee National Park of Canada, 2012. Point Pelee National Park Library, Parks Canada, Leamington, Ontario. 2013 
37. Watson TG, Anderson RC. Ixodes scapularis Say on white-tailed deer (Odocoileus virginianus) from Long Point, Ontario. J Wildl Dis. 1976; 12: 66-71. http://dx.doi.org/10.7589/0090-3558-12.1.66

38. Scrimenti RJ. Erythema chronicum migrans. Arch Dermatol. 1970; 102: 104-105. doi: 10.1001/archderm.1970.04000070106017

39. Lindsay LR, Barker IK, Surgeoner GA, et al. Survival and development of Ixodes scapularis (Acari: Ixodidae) under various climatic conditions in Ontario, $\begin{array}{lllll}\text { Canada. J } & \text { Med } & \text { Entomol. 1995; } & \text { 32: }\end{array}$ http://dx.doi.org/10.1093/jmedent/32.2.143

40. Vandyk JK. Survival of Ixodes scapularis (Acari: Ixodidae) exposed to cold. J Med Entomol. 1986; 33: 6-10. http://dx.doi.org/10.1093/jmedent/33.1.6

41. Heisig M, Abraham NM, Liu L, et al. Antivirlence properties of an antifreeze $\begin{array}{lllll}\text { protein. } & \text { Cell } & \text { Reports. } & \text { 2014; } & \text { 9: }\end{array}$ http://dx.doi.org/10.1016/j.celrep.2014.09.034

42. Loken $\mathrm{KL}, \mathrm{Wu} \mathrm{C}-\mathrm{C}$, Johnson RC, et al. Isolation of the Lyme disease spirochete from mammals in Minnesota. Exp Biol Med. 1985; 3: 300-302. doi:10.3181/00379727-179-42100

43. Peavey CA, Lane RS. Transmission of Borrelia burgdorferi by Ixodes pacificus nymphs and reservoir competence of deer mice (Peromyscus maniculatus) infected by tick-bite. J Parasitol. 1995; 81: 175-178. http://www.ncbi.nlm.nih.gov/pubmed/7707191

44. Anderson JF, Magnarelli LA. Avian and mammalian hosts for spirochete-infected ticks and insects in a Lyme disease focus in Connecticut. $\begin{array}{lllll}\text { Yale J } & \text { Biol }\end{array}$ http://www.ncbi.nlm.nih.gov/pubmed/6516460

45. Telford III SR, Mather TN, Adler GH, et al. Short-tailed shrews as reservoirs of the agent of Lyme disease and human babesiosis. J Parasitol. 1990; 76: 681-683. http://www.jstor.org/stable/3282982

46. Anderson JF, Magnarelli LA, Burgdorfer W. Spirochetes in Ixodes dammini and mammals from Connecticut. Am J Trop Med Hyg. 1983; 32: 818-824. http://www.ncbi.nlm.nih.gov/pubmed/6881431

47. McLean RG, Ubico SR, Cooksey LM. Experimental infection of the eastern chipmunk (Tamias striatus) with the Lyme disease spirochete (Borrelia $\begin{array}{llll}\text { burgdorferi). J Wildl } & \text { Dis. 1993; 29: }\end{array}$ http://www.ncbi.nlm.nih.gov/pubmed/8258849

48. Markowski D, Ginsberg HS, Hyland KE, et al. Reservoir competence of the meadow vole (Rodentia: Cricetidae) for the Lyme disease spirochete Borrelia burgdorferi. J Med Entomol. 1998; 35: 804-808. doi: 10.1093/jmedent/35.5.8044

49. Stone BL, Russart NM, Gaultney RA, et al. The western progression of Lyme disease: infectious and nonclonal Borrelia burgdorferi sensu lato populations in Grand Forks County, North Dakota. Appl Environ Microbiol. 2015; 81: 48-58. doi: 10.1128/AEM.02422-14

50. Telford III SR, Mather TN, Moore SI, et al. Incompetence of deer as reservoirs of the Lyme disease spirochete. Am J Trop Med Hyg. 1988; 39: 105-109. http://www.ncbi.nlm.nih.gov/pubmed3400797

51. Anderson JF. Mammalian and avian reservoirs for Borrelia burgdorferi. Ann New York Acad Sci. 1998; 539: 180-191. doi:10.1111/j.1749-6632.1988.tb31852.x

52. Anderson JF, Magnarelli LA. Enzootiology of Borrelia burgdorferi in the northeastern and northcentral United States. Biology of Ixodes ricinus complex ticks and Lyme disease. Acarology IX Symposia. 1999; 2: 385-389.

53. Ostfeld RS, Canham CD, Oggenfuss K, et al. Climate, deer, rodents, and acorns as determinants of variation in Lyme-disease risk. PLoS Biol. 2006; 4: e145. doi:10.1371/journal.pbio.0040145

54. Stafford III KC. Oviposition and larval dispersal of Ixodes dammini (Acari: Ixodidae). J Med Entomol. 1992; 29: 129-132. doi:10.1093/jmedent/29.1.129

55. Carroll JF. Occurrence of larval Ixodes scapularis (Acari: Ixodidae) on tree trunks. J Med Entomol. 1996; 33: 971-975. PMID: 8961648

56. Ladislav S, Sonenshine DE, Park Y, Žitňan D. Nervous and sensory systems: structure, function, genomics, and proteomics. In: Sonenshine DE \& Roe RM, eds. Biology of Ticks, 2nd ed., Vol. 1. Oxford, England; New York, United States: Oxford University Press; 2014: 309-367.

57. Rand PW, Lubelczyk C, Holman MS, et al. Abundance of Ixodes scapularis (Acari: Ixodidae) after the complete removal of deer from an isolated offshore island, endemic for Lyme disease. J Med Entomol. 2004; 41: 779-784. doi: http://dx.doi.org/10.1603/0022-2585-41.4.779

58. Scott JD. Birds widely disperse pathogen-infected ticks. In: Mahala G, ed. Seabirds and Songbirds: habitat preferences conservation and migratory behavior. Birds-evolution, behavior and ecology. New York: Nova Science Publishers, Inc.; 2015: 1-22.

59. Scott JD, Durden LA, Anderson JF. Infection prevalence of Borrelia burgdorferi in ticks collected from songbirds in far-western Canada. Open J An Sci. 2015; 5: 232-241. http://dx.doi.org/10.4236/ojas.2015.53027

60. Scott JD, Durden LA. Songbird-transported tick Ixodes minor (Ixodida: Ixodidae) discovered in Canada. Can Entomol. 2015; 147: 46-50. doi:10.40339/tce.2014.34

61. Scott JD, Durden LA. First record of Amblyomma rotundatum tick (Acari: Ixodidae) parasitizing a bird collected in Canada. Syst Appl Acarol. 2015; 20: 155-161. http://dx.doi.org/10.11158/saa.20.2.1

62. Scott JD, Durden LA. Amblyomma dissimile Koch (Acari: Ixodidae) parasitizes bird captured in Canada. Syst Appl Acarol. 2015; 20: 854-860. http://dx.doi.org/10.11158/saa.20.8.2

63. Scott JD, Clark KL, Foley JE, et al. First record of Ixodes affinis tick (Acari: Ixodidae) infected with Borrelia burgdorferi sensu lato collected from a migratory songbird in Canada. J Bacteriol Parasitol. 2016; 7: 3. http://dx.doi.org/10.4172/2155-9597.1000281
64. Stafford KC. Impact of controlled burns on the abundance of Ixodes scapularis (Acari: Ixodidae). J Med Entomol. 1998; 35: 510-513. www.entsoc.org/PDF/Pubs/Periodicals/JME/JMETOCS/PDF/me04980051 $0 . p d f$

65. Wilson ML. Reduced abundance of adult Ixodes dammini (Acari: Ixodidae) following destruction of vegetation. J Econ Entomol. 1986; 79: 693-696. doi:10.1093/jme/79.3.693

66. Mather TN, Duffy DC, Campbell SR. An unexpected result from burning vegetation to reduce Lyme disease transmission risks. J Med Entomol. 1993; 30: 642-645. doi:10.1093/jmedent/30.3.642

67. Stafford KC, Kitron U. Environmental management for Lyme borreliosis control. In: Gray J, Kahl O, Lane RS, Stanek G, eds. Lyme borreliosis. Wallingham, England: CAB International; 2002: 301-334.

68. Stafford KC. Tick Management Handbook. The Connecticut Agricultural Experiment Station. South Windsor, Connecticut, USA: EPS Printing II, LLC; 2007.

69. Cook MJ. Lyme borreliosis: a review of data on transmission time after tick attachment. Int J Gen Med. 2015; 8: 1-8. doi:10.21447/IJGM.S73791

70. Ebel GD, Kramer LD. Short report: duration of tick attachment required for transmission of Powassan virus by deer ticks. Am J Trop Med Hyg. 2004; 71: 268-271. http//www.ajtmh.org/content/71/3/268.full.pdf+html

71. Forrester JD, Meiman J, Mullins J, et al. Update on Lyme carditis, groups at high risk, and frequency of associated sudden cardiac death - United States. MMWR. 2014; 68: 682-983. www.cdc.gov/mmwr/preview/mmwrhtml/mm6343a4.htm

72. Stonehouse A, Studdiford JS, Henry A. An update on the diagnosis and treatment of early Lyme disease: "focusing on the bull's eye, you may miss the mark." J Emerg Med. 2010; 39: e147-e151. jdc.jefferson.edu/cgi/viewcontent.cgi?article $=1007 \&$ context $=\mathrm{fmfp}$

73. Berger BW, Krueger JG, Eshoo MW. Atypcial erythema migrans in patients with PCR-positive Lyme disease. Emerg Inf Dis. 2013; 19: 815-817. doi: 10.3201/eid1905.120796

74. Schuttelaar ML, Laeijendecker R, Heinhui RJ, et al. Erythema multiforme and persistent erythema as early cutaneous manifestations of Lyme disease. Am Acad Dermatol. $\quad 1997 ; \quad 37$ 873-875. http://dx.doi.org/10.1016/SO190-9622(97)80015-1

75. Cameron DJ, Johnson LB, Maloney EL. Evidence assessments and guideline recommendations in Lyme disease: the clinical management of known tick bites, erythema migrans rashes and persistent disease. Expert Rev Anti Infect Ther. 2014; 12: 1103-1135. doi:10.1586/14787210.2014.940900

76. Miklossy J. Bacterial amyloid and DNA are important constituents of senile plaques: further evidence of the spirochetal and biofilm nature of senile plaques. J Alzheimers Dis. 2016; 53: 1459-1473. doi: 10.3233/JAD-160451

77. Dorward DW, Fischer ER, Brooks DM. Invasion and cytopathic killing of human lymphocytes by spirochetes causing Lyme disease. Clin Infect Dis. 1997; 25 (Suppl 1): S2-S8. http:// www.jstor.org/stable/4460119

78. Zijkowska JM, Hermanowska-Szpakowicz T. New aspects of the pathogenesis of Lyme disease. Przeglad Epidemiologiczny. 2002; 56 (Suppl 1): S57-S67. http://www.ncbi.nlm.nih.gov/pubmd/12194230

79. Horowitz RI. Why can't I get better? Solving the mystery of Lyme \& chronic disease. New York, USA: St. Martin's Press; 2013.

80. Peacock BN, Gherezghiher TB, Hilario J. New insights into Lyme disease. Redox Biol. 2015; 5: 66-70. http://doi.org/10.1016/j.redox.2015.03.002

81. Oksi J, Kalimo H, Marttila RJ, et al. Inflammatory brain changes in Lyme borreliosis: a report on three patients and review of literature. Brain. 1996; 119: 2143-2154. doi:10.1093/brain/119.6.2143

82. MacDonald AB. Alzheimer's neuroborreliosis with trans-synaptic spread of infection and neurofibrillary tangles derived from intraneuronal spirochetes. Med Hypotheses. 2007; 68: 822-825. doi:10.1016/j.mehy.2006.08.043

83. Miklossy J. Alzheimer's disease-a neurospirochetosis. Analysis of the evidence following Koch's and Hill's criteria. J Neuroinflammation. 2011; 8: 90. http://www.jneuroinflammation.com/content/8/90

84. Oksi J, Mertsola J, Reunanen M. Subacute multiple-site osteomyelitis cause by Borrelia burgdorferi. Clin Infect Dis. 1994; 19: 891-896. doi:10.1093/clinids/19.5.891.

85. Häupl T, Hahn G, Rittig M, et al. Persistence of Borrelia burgdorferi in ligamentous tissue from a patient with chronic Lyme borreliosis. Arthritis Rheum. 1993; 36: 1621-1626. doi:10.1002/(ISSN)1529-0131

86. Müller ME. Damage of collagen and elastic fibres by Borrelia burgdorferi known and new clinical histopathogical aspects. Open Neurol J. 2012; 6 (Suppl 1-M11): S179-S186. doi:10.2174/1874205X01206010179

87. Preac-Mursic V, Pfister HW, Spiegel H, et al. First isolation of Borrelia burgdorferi from an iris biopsy. J Clin Neuroophthalmol. 1993; 13: 155-161. http://journals.lww.com/jneuro-ophthalmology/Abstract/1993/09000/

88. Ramesh G, Borda JT, Dufour J, et al. Interaction of the Lyme disease spirochete Borrelia burgdorferi with brain parenchyma elicits inflammatory mediators from glial cells as well as glial and neuronal apoptosis. Am J Pathol. 2008; 173: 1415-1427. doi:10.2353/ajpath.2008.080483

89. Ramesh G, Santana-Gould L, Inglis FM, et al. The Lyme disease spirochete Borrelia burgdorferi induces inflammation and apoptosis in cells from dorsal $\begin{array}{lllll}\text { root ganglia. J Neuroinflammation. 2013; } & 10: & 88 .\end{array}$ http://www.jneuroinflammation.com/content/10/1/88

90. Frey $M$, Jaulhac $B$, Piemont $Y$, et al. Detection of Borrelia burgdorferi DNA in muscle of patients with chronic myalgia related to Lyme disease. Am J Med. 1998; 104: 591-594. doi:10.1016/S0002-9343(98)00112-0 
91. Klempner MS, Noring R, Rogers RA. Invasion of human skin fibroblasts by the Lyme disease spirochete, Borrelia burgdorferi. J Infect Dis. 1993; 167: 1074-1081. doi:10.1093/infdis/167.5.1074

92. Meriläinen L, Herranen A, Schwarzbach A, et al. Morphological and biochemical features of Borrelia burgdorferi pleomorphic forms. Microbiol. 2015; 161: 516-527. doi:10.1099/mic.0.000027

93. Lewis K. Persister cells, dormancy and infectious disease. Nature Rev Microbiol. 2007; 5: 48-56. doi:10.1038/nrmicro1557

94. Liegner KB, Duray P, Agricola M, et al. Lyme disease and the clinical spectrum of antibiotic responsive chronic meningoencephalomyelitides. J Spir
Tick-borne
Dis.
1997;
4:
$61-73$. www2.lymenet.org/Domino/abstract.nsf/8c703fae46ce57c28525670a0009

95. Middelveen MJ, Burke J, Sapi E, et al. Culture and identification of Borrelia spirochetes in human vaginal and seminal secretions. F1000Research. 2015; 3 : 309. doi:10.12688/f1000research. 5778.3

96. Stricker RB, Middelveen MJ. Sexual transmission of Lyme disease: challenging the tickborne disease paradigm. Expert Rev Anti-Infect Ther. 2015; 13: 1303-1306 doi:10.1586/14787210.2015.1081056

97. Embers ME, Barthold SW, Borda T, et al. Persistence of Borrelia burgdorferi in rhesus macaques following antibiotic treatment of disseminated infection. PLoS ONE. 2012; 7: e29914. doi:10.1371/journal.pone.0029914

98. Hodzic E, Imai D, Feng S, et al. Resurgence of persisting non-cultivable Borrelia burgdorferi following antibiotic treatment in mice. PLOS ONE. 2014; 9: e86907. doi:10.1371/journal.pone.0086907 